\title{
Depiction of A Solar Eclipse from 1143 BCE in the Pharaonic Tomb KV9 near Thebes
}

\author{
Klaus Hentschel* \\ Head of the Section for the History of Science and Technology, University of Stuttgart, Germany.
}

*Corresponding Author: Klaus Hentschel, Section for the History of Science and Technology, University of Stuttgart, Germany. http://www.hi.uni-stuttgart.de/institut/team/Hentschel

\begin{abstract}
A remarkable part of the ceiling mural in corridor $G$ to the burial chamber of Tomb KV 9 for Pharaohs Ramesses V and VI is interpreted as depicting a solar eclipse in 1143 BCE, which reached 80\% totality in the Theben region and full totality further south in the Syene (Assuan) region of Ancient Egypt. This mural agrees perfectly with the book Amduat on the walls of corridor $G$ whose 12th hour it replaces. In the 20th dynasty, a solar eclipse was interpretable as a momentary unification of Ra (the sun) and Osiris (the moon).
\end{abstract}

\section{INTRODUCTION}

Tomb KV9 in the Valley of the Kings in western Thebes (see Fig. 1 for the layout of the tomb), originally cut into the rock for Ramesses V and later usurped and expanded by Ramesses VI, is famed for its celestial depictions. One of these motifs on a dropped section of the ceiling at the end of corridor $\mathrm{G}$ has hitherto only received passing mention. Ramesses V and Ramesses VI are both known to have been particularly interested in the heavens. The tomb is copiously adorned with the canopy of stars and other celestial objects.[1]

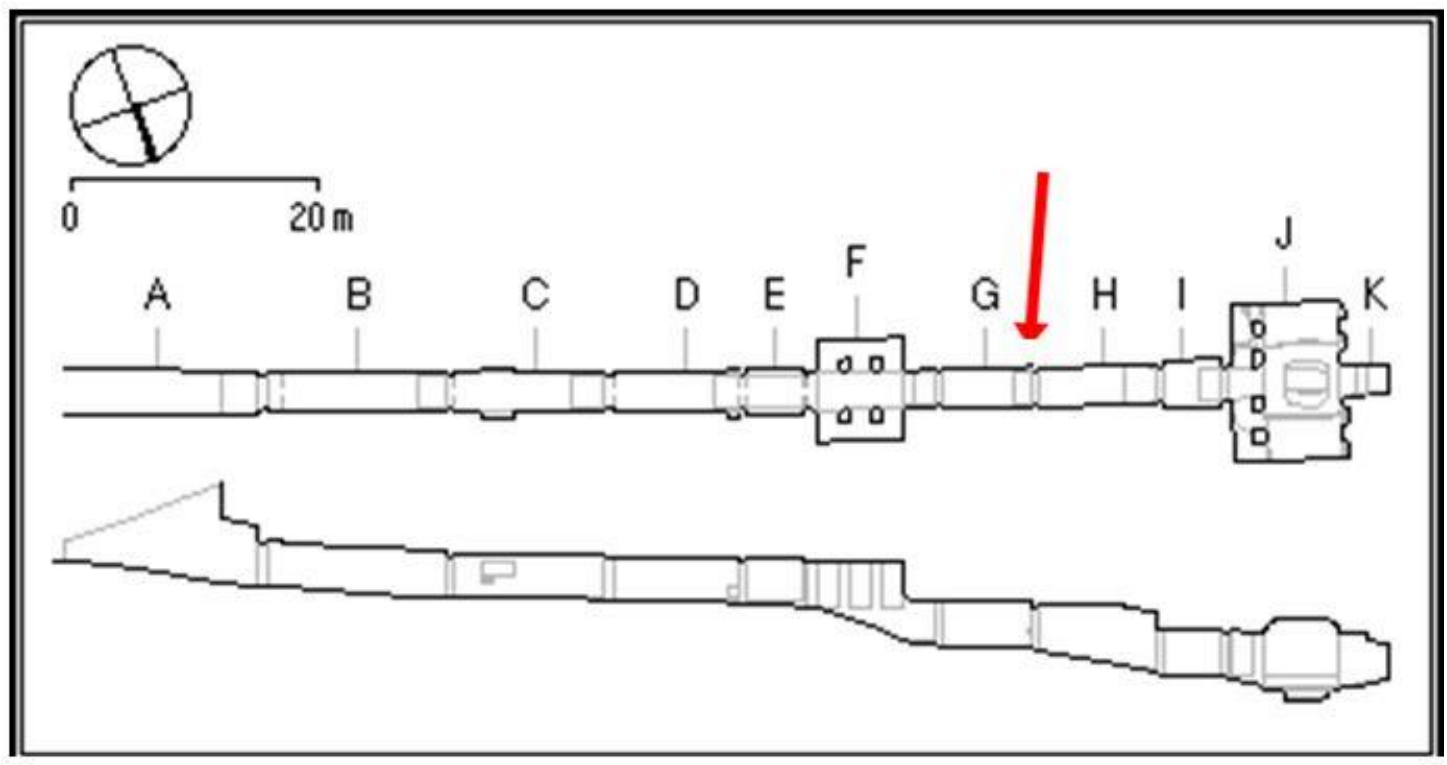

Fig. 1 Top and side-view plan of Tomb KV9 from the Theban Mapping Project. The arrow (added by the author) marks the position of the ceiling mural http://www.kv5.de/html_german/data_kv9_german.html

Graffiti dating from the first century BCE to the fourth century AD attest to its fame among pilgrims of the Ancient world: The Romans attributed the tomb to Memnon. Its emphasis on the voyage of the dead through the netherworld led members of the Napoleonic expedition in the early nineteenth century to refer to it as "la tombe de la métempsychose." Its excerpts from the ancient Egyptian books of the underworld are as unusually detailed as are its cosmological depictions. [2] A 3-D documentary scan of the tomb released by the Egyptian Tourism Authority in 2020 allows anyone to take a virtual tour through the site and view the spaces, murals and reliefs from all angles.[3] 


\section{Brief Description Of The Ceiling Mural at The End Of Corridor G}

Let's start with a brief description of the mural in question. In Figure 2 one sees a yellow disk resting on top of a sicle-shaped area of a slightly different tint not much darker but more intense, with a slightly reddish tinge - please also compare with the detail photograph in Figure 7 taken by the author.

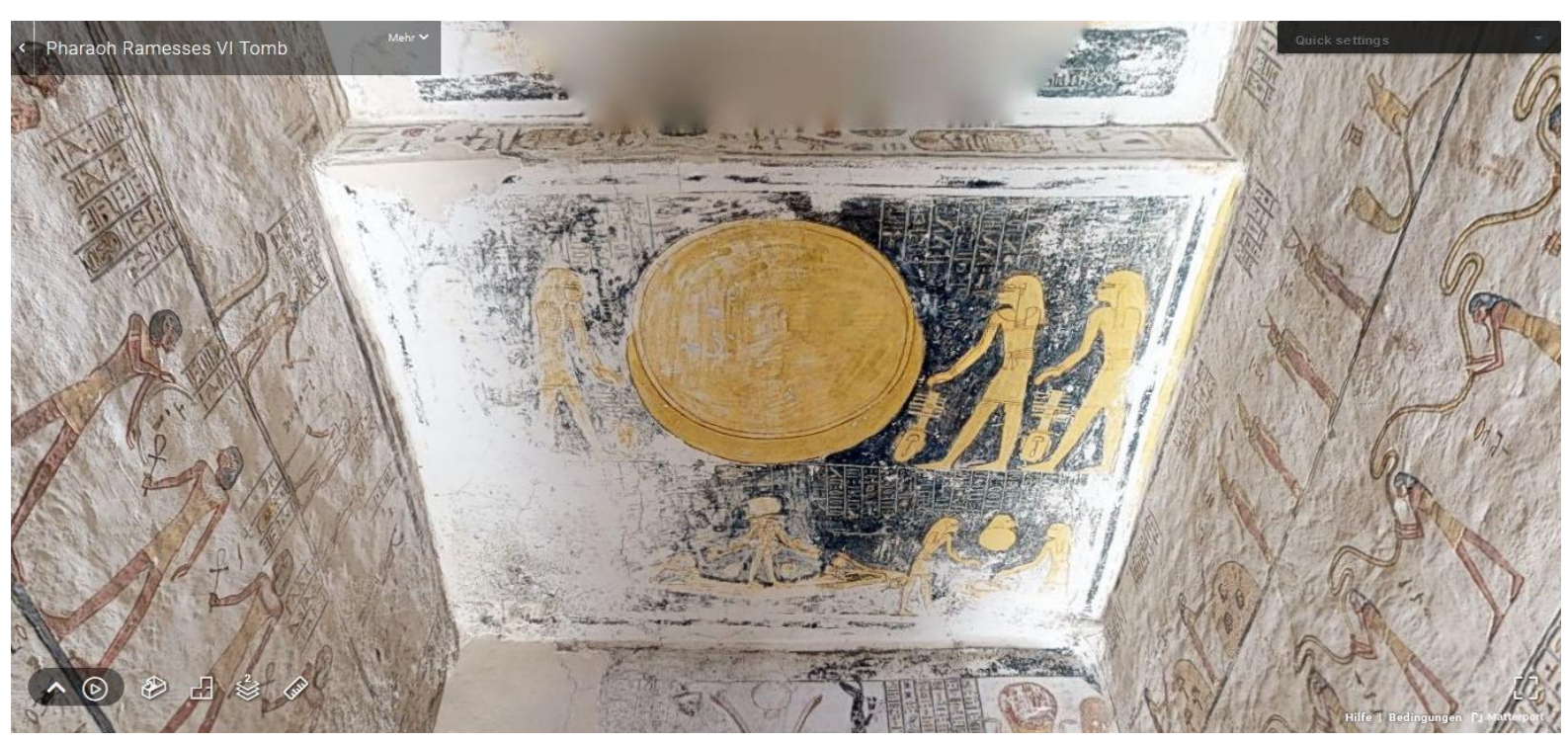

Fig. 2 The depiction of a solar eclipse in Tomb KV9 at the end of corridor $G$ (screenshot from the 3-D documentary video by the Egyptian Tourism Authority, released on 15 April 2020)

The disk is flanked on either side by two gods, each holding what appears to be the arched grip at the top of an instrument (better discernible in the high-resolution black-and-white photograph in Darnell 2004-here Fig. 3) propped at their feet.

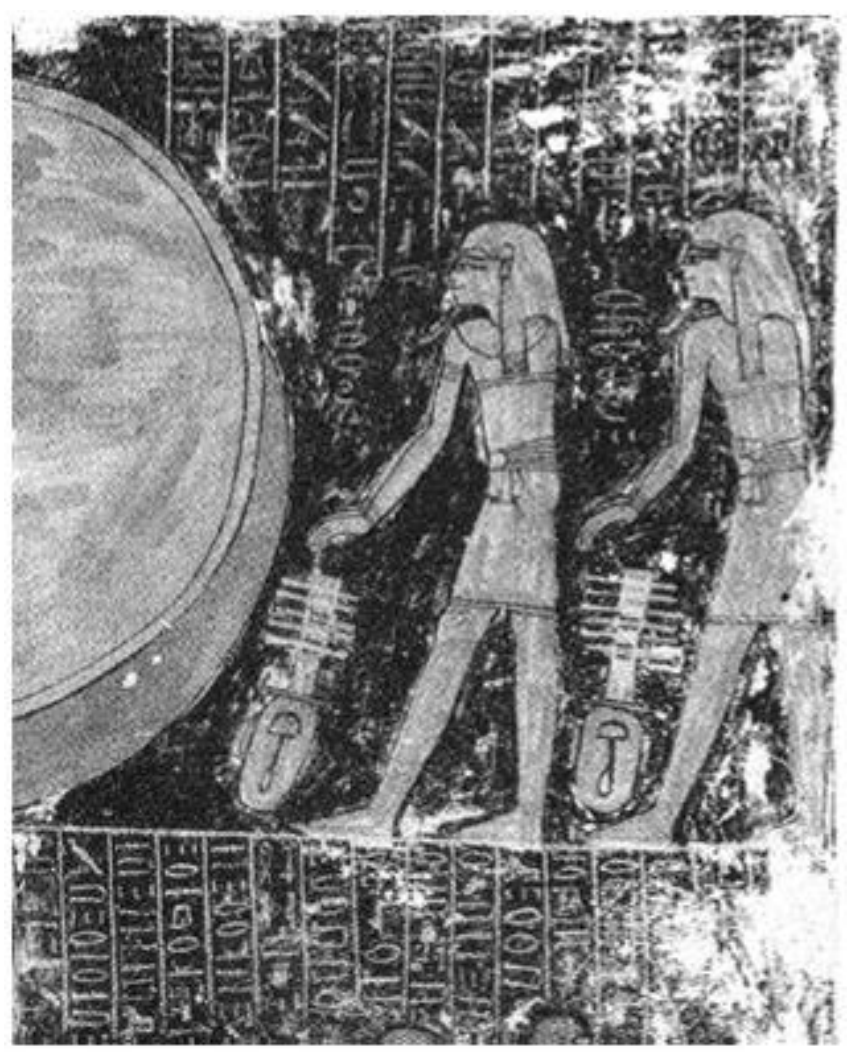

Fig. 3 Close-up of the two male figures to the right of the disk, each holding a musical instrument, either a kind of lute or a sistrum or rattle, often used in rituals honoring the goddesses Hathor and Isis.

The still legible part of the enigmatic hieroglyphs can be seen above and below it. (excerpt from Plate 27 in Darnell 2004). These strange hieroglyphs are decrypted as follows: "That which is in the mouths 
comes forth before them against these shades, in order to destroy them, the deities being surrounded by <their> manifestations." ... "The deity goes around while being at peace." ... "It is while going about in peace that the deity breathes. This deity knows that he shines. If their spells come forth to him, they will breathe." (Darnell 2004, pp. 227, 228).

As Figure 4 shows, it is plausible to interpret them figuratively as a sistrum or rattle, i.e. as musical instruments rather than as merely cryptographic symbols for nefer or sa.t,[4] since they are drawn far too naturalistically. The fact that these instruments are not actually being played but held afoot of the two gods might well be a way to depict awed astonishment at the phenomenon that the two pairs of gods are watching.[5]
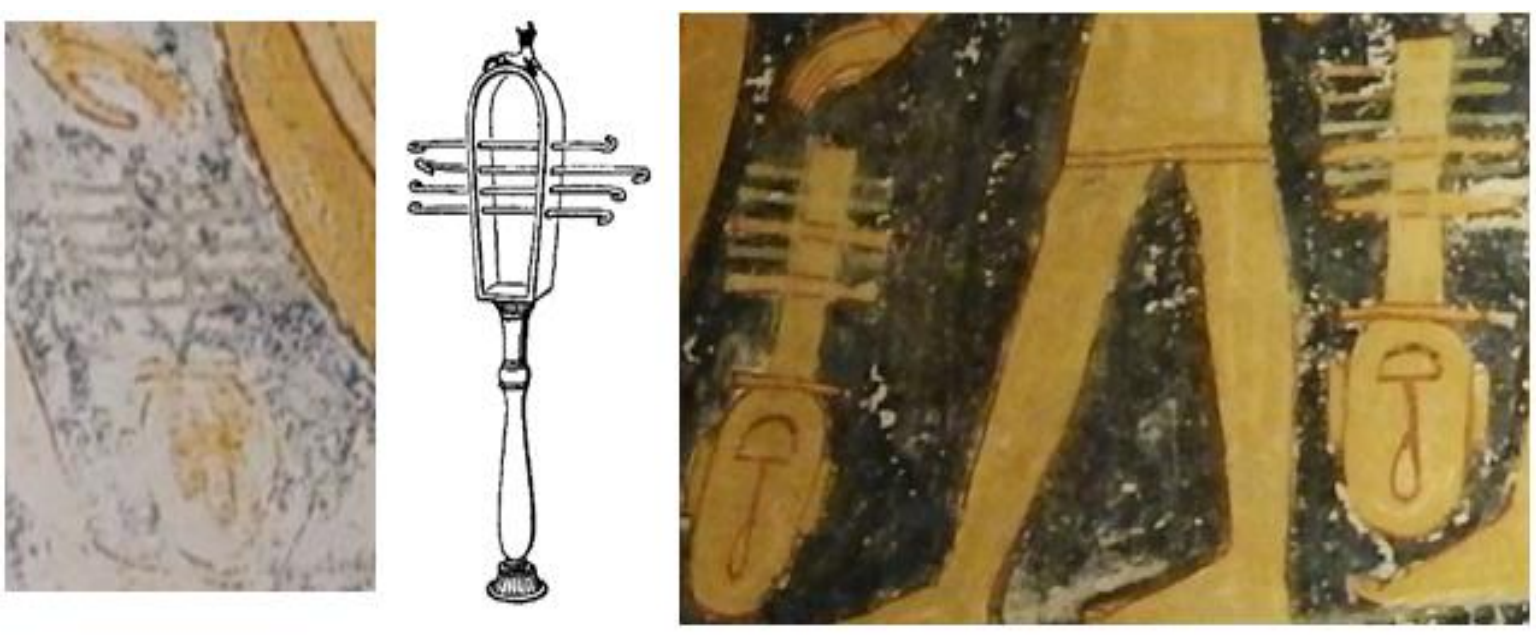

Fig. 4 Comparison of the upper part of the objects held in Figure 3 (photographs by the author) with a sistrum of the type particularly used in Isis dances (according to Juvenal 13:93+), from Encyclopaedia Biblica (1903), fig. 5 in the article on music; cf. also https://en.wikipedia.org/wiki/Sistrum for this and further images.

On the lower register we see the barque of the deity of the sun Ra (Fig. 5)

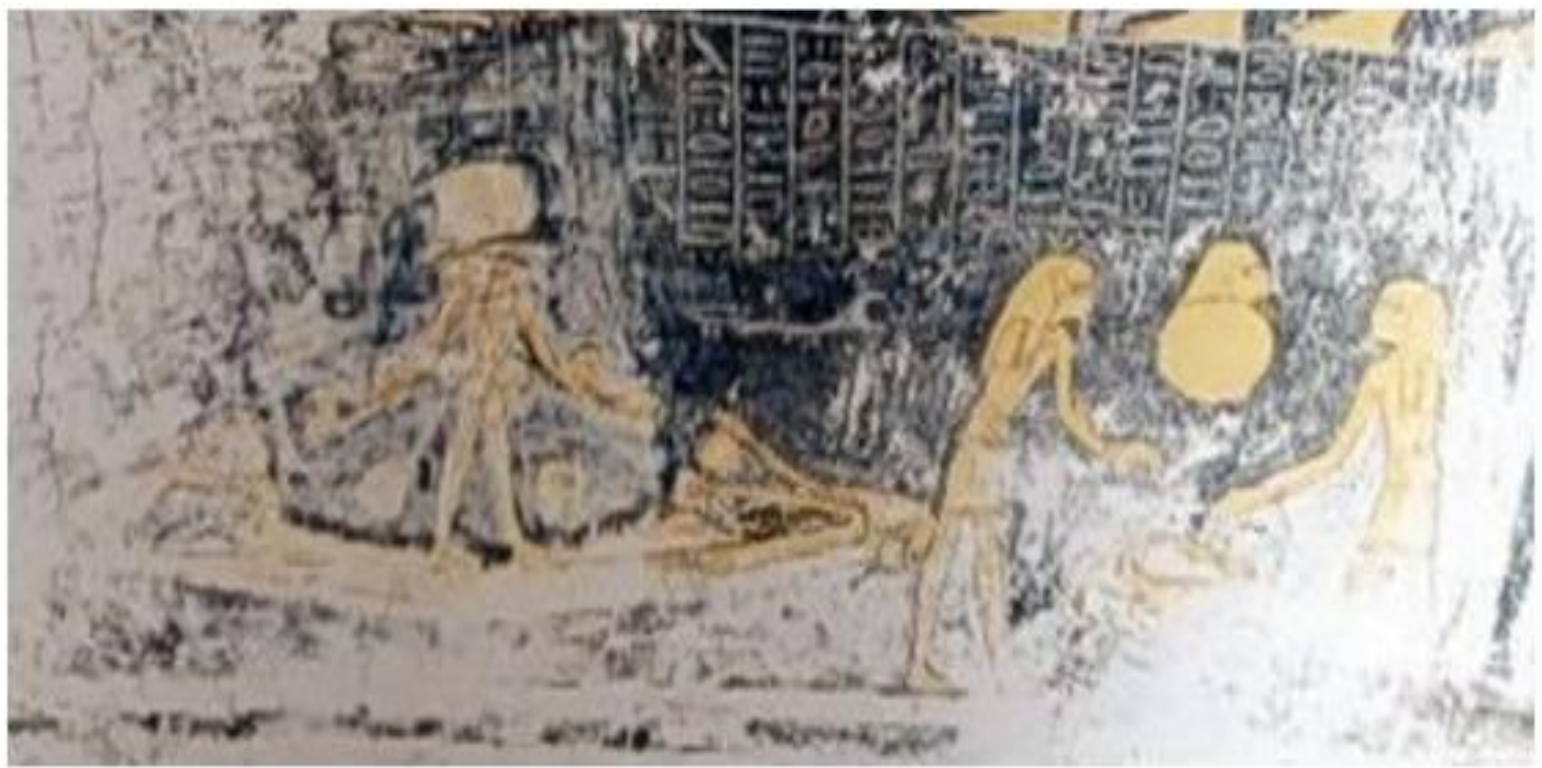

Fig. 5 The vessel of the netherworld: The personified barque of Ra, its deck constituting a male double deity whose two pairs of arms are passing the solar disks to and fro double-headed Ra (from Abitz 1989: 154)

The left-hand side of this mural is unfortunately badly preserved, but the upper part of it appears to be arranged in strict symmetry to the right side. John D. Darnell has partly succeeded in deciphering the cryptographic or enigmatic inscriptions that one sees at the upper right.[6] The background is very dark, almost black throughout, whereas everywhere else, apart from the starry sky, the background is very bright, for instance, the walls on either side of corridor G in Figure 2.

The line drawing of the mural in Figure 6 shows details of the barque of $\mathrm{Ra}$ in the lower field more clearly. 


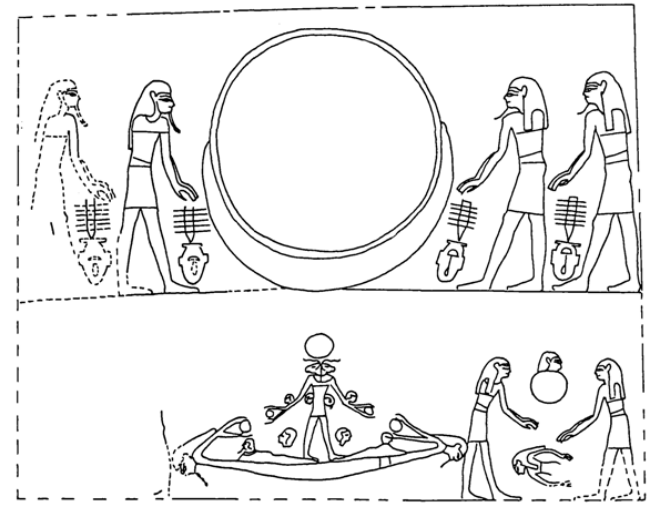

Fig. 6 Outline of the dropped section of the ceiling at the end of corridor G (from Abitz 1989: 153)

The deck of the personified vessel is a double deity with two bearded heads and two pairs of arms that are passing the solar disks to the sun god (his two ram's heads pointing east and west). He is standing on the barque, his feet planted on the bodies of two prostrate gods. A falcon head protrudes from each side of his torso and his arms are tossing the solar disks into the arms of the double deity constituting the barque. [7] To the right of the barque scene, two gods are tossing to each other a headed solar disk symbolizing the sun deity $\mathrm{Ra}$ on its diurnal journey and a supine figure symbolizing the sun on its nocturnal journey. (Fig. 6) This is yet another signification of the cyclical alternation between day (sun) and night (moon), between life and death. [8]

The most detailed description and documentation of the excerpt of the mural in tomb KV9 of interest here only remarks that one sees "a large solar disk with a lunar sicle" below it, "this here surely being the union between day and night or between $\mathrm{D}[\mathrm{u}]$ at and the sky."'[9] There is unfortunately no further comment in the existing literature about the pairs of flanking instrument-bearing male figures.[10] Abitz concludes about this two-part mural on the jutting segment of the ceiling at the end of corridor G: "Both these ceiling images depict the netherworld journey of the sun god to the birth of the sun, evidently at the instant when the first rays of sunlight appear in the east and the gradually fading stars are still present in the west, a realistic image of the union between the underworld and the sky [Himmel], or night and day."[11] This applies quite well to the lower register with the barque of Ra but not to the upper one. Obviously, night and day, or dark and light are the subject matter but, I think, in an entirely different context as a virtually unique motif for Ancient Egypt: namely a solar eclipse, presenting this play of light and full solar disk collapsed into a short space of time. The present paper interprets the image not as a full disk on top of a lunar crescent but rather as the full moon disk superimposed on the sun, with the rim of the sun peeping out below. Whereas in the crown of moon-god Chons, well-known from various paintings in the Theben tombs,[12] the disk is situated above the moon sicle like a ball on a slightly less curved bowl with its tips not touching the disk, our image in figure 2 definitely shows two full circles, overlapping each other by about $85 \%$ without any gap in between.
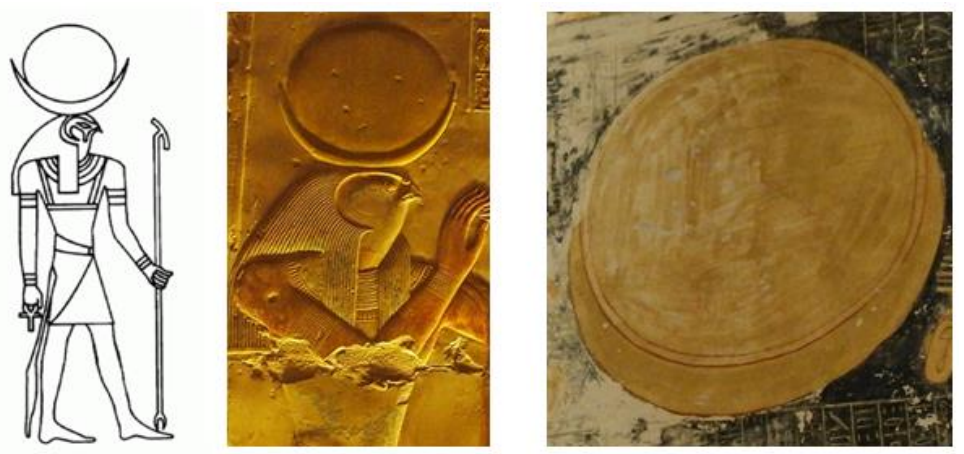

Fig. 7 Comparison between two typical depictions of the moon god Khonsu / Chons (left and middle), who is normally represented with a falcon head crowned with a (yellowish) moon sicle carrying a (sometimes reddish) disk of smaller radius, and our motif (right) - a free-standing superposition of two full circles, of which the one in the foreground is less regularly painted in light ocre, the one in the back slightly more intense and far more regularly painted (from https://www.selket.de/aegyptische-goetter/chons/ resp. photo by the author in tomb KV9, taken in February 2020). 
Our image (fig. 2) thus differs in size, arrangement, and color from the Chons symbol. It suits this new interpretation very well that the light color of these two yellow areas does differ considerably as Darnell's black-and-white details (Fig. 3) shows. They are almost equally bright. The color photograph in Figure 2 shows that the underlying sicle is much more homogeneously colored in a slightly reddish hue, whereas the circular ochre-yellow disk is strangely pallid and appears somewhat mottled, almost the way the moon's surface looks when observed with the naked eye. The distribution of blotches and fuzzy edges suggests that this is not the result of erosion or later modifications due to excavation, visitor exposure or inappropriate restoration but is an intended effect to show a rough, irregular surface. Contrary to the conventional interpretation of such depictions, my hypothesis is that in this case the lower almost completely occulted figure is the sun and the area in front of it is the disk of the moon, which is momentarily eclipsing the sun. The color differences support this argument because in many Theban tombs the sun is represented as reddish and the moon is yellower and paler. [13]

\section{THE PLACEMENT OF THE IMAGE AND ITS SIGNIFICANCE}

The end of corridor $\mathrm{G}$ was a conspicuous spot where the record of the netherworld book Amduat (also called "Text of the Hidden Chamber") on the flanking walls breaks off. As Friedrich Abitz (1989: 99110) has shown, in this otherwise complete record in the tomb of Ramesses VI, the final 12th hour of the Amduat, which recounts the rebirth of the sun, is missing. At this truncation point, the account of so rare and unusual an event as a solar eclipse, inserted on the dropped ceiling portion at the end of corridor G, is an apt substitute. For, a solar eclipse is a condensed form of that mythical "rebirth of the sun" mentioned in the Book of the Earth, also known as Book of the Rebirth of the Sun,[14] which is extensively reproduced in the subsequent final section of Tomb KV9 from the 20th dynasty. After its brief eclipse behind the obscuring moon, the sun gradually reemerges again.

Both registers of our depiction (in Figs. 2-5) contain the above-mentioned "cryptographic or enigmatic inscriptions" also to be found in the tombs of Tutankhamun and Ramesses IX among others-Darnell (2004) has succeeded in deciphering them at least in part. According to his account, particularly during the New Kingdom such cryptographic symbols had strong astronomical and solar connotations because they averred the union of the sun god Ra and Osiris and were supposed to remind the knowledgeable visitor that this tomb is in the legendary and highly dangerous region where Osiris and Ra become one at rebirth. (Darnell 2004: abstract) The stages along their path and their struggles before this rebirth are described in the 12 books of the netherworld, the Amduat, only the first eleven of which are presented on the walls of corridor $G$ leading up to the dropped ceiling section.[15]Abitz and Darnell both interpret the bright disk on the sicle of the underlying disk as the "union of day and night or of $\mathrm{D}[\mathrm{u}] \mathrm{at}$ with the sky" and this alternation between the solar and lunar disks demonstrate the "perpetuum mobile of the solar cycle."[16] I second this idea insofar as a solar eclipse, which is the result of the solar and lunar cycles coinciding, may also represent such a "union of day and night," of brightness and darkness, of sun and moon. "Both the sun and the moon are the eyes of the Creator" (Assmann 1983: 256f.), whose creation begins with the rising of the sun, just as every day starts with the new sunrise. "Light is the glance by which the Creator looks at his world [...]. This light darts into all corners. There is no limit to divine attention. Nothing escapes his glance. "It is I who opens his eyes and there is light; who closes his eyes, and there is darkness"' (Papyrus Turin Tf. 133, 8). [17]

No natural phenomenon brings the sun and moon into closer relation from the human point of view than a solar eclipse. How could such momentous events have been so much ignored in Ancient Egypt as the existing secondary literature by Egyptologists would have it? Wouldn't it have been mandatory for a pharaoh to incorporate such a momentous experience occurring during his reign into the murals of his tomb? After all, he did consider himself the earthly agent of the sun god Amun-Ra. A solar eclipse interrupts the regular succession of light and dark, or day and night, which was a pharaoh's responsibility.[18] There must have been quite some pressure to come up with some justification when the regular order of things was interrupted that way, however briefly. Disruptions of that "sympathetic relationship between the cosmos and society," of the regular course of the sun and stable human order, which it fell upon the pharaoh to guarantee, were perceived as a catastrophe that could only be prevented by strict abidance by the ritualistic ceremonies of the cult.[19] 
People have generally been mystified about why the $12^{\text {th }}$ hour of the Amduat had been omitted from the otherwise complete record on the murals of corridor G. According to my reading, the mural on the dropped ceiling (in our Fig. 2) takes the place of hour 12, which describes the rebirth of the sun. The dominant image in the "sentinel image"[20] in the next transitional passage leading to the tomb chamber area, is of Ra-Osiris with legs terminating in four snakes, which intends to display the full brilliance of the shining sun, but its cryptic annotation refers back to the figure of the sun deity, whom we had met in the lower register of Fig. 2 standing on the sun barque formed by the body of the double god: "This is how he [this sun god] is composed: his arms are two snakes, which he leaves in his sun disk."'[21] This is good evidence that the sentinel image belongs with those in corridor G including the dropped-ceiling mural. A practically complete reproduction of the so-called Book of the Earth (which could also be called the Book of the Birth of the Sun Disk) is displayed in the tomb chamber area. [22] It treats the daily rebirth of the sun, when it is devoured in the evening by Nut, follows its course through the underworld and is reborn again in the morning. The reemergence of the sun after an eclipse is just as well a rebirth of a kind. In Ancient Egypt the sun's course was understood as a kind of "pulse beat of the cosmos conceived as a process" in which creation is repeated day after day. [23] So a solar eclipse must have been a notable natural event also for Ancient Egyptians. It temporarily interrupts the natural cycle of day and night, light and dark. Consequently, solar eclipses must have been extremely unsettling in Ancient Egypt. [24]

During the twentieth dynasty Amun-Ra was conceived as the divine ruler of the sky. The pharaoh was his representative on Earth (from the fourth dynasty on, he was even worshipped as the "son of Ra") and his power was boundless. The shining rays of the sun, at that time often also interpreted as dreadful radiance, was affectively translated into the aura of might.[25] Any sudden interruption of this might - say, by dimming daylight during an eclipse-would have been interpreted as an extremely bad omen, as the sun being "swallowed up by the sky."[26] What had happened to the pharaoh's omnipotence? Or was this due punishment for some relapse? Quite contrary to the Babylonian case.

Few sources from Ancient Egypt have come to light as unambiguous records of any reaction to a solar eclipse.[27] Is it possible that some still existing sources so far have just been misunderstood? The anthropologist David G. Smith is convinced that he has identified some instances that professional Egyptologists such as Jan Assmann have dismissed as accounts of sudden fits of blindness or temporary onsets of darkness. His texts and vignettes come from Deir el-Medina, an ancient workers' settlement very close to the Valley of the Kings near Thebes, taken from columns among the ruins or from tombs of officials, artisans and court servants. Here is one particularly impressive example: [28]

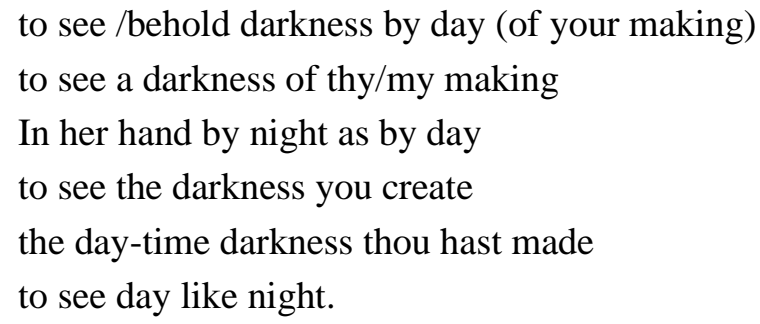

These reanalyzed and reinterpreted texts by Smith are dated to the reign of Ramesses II, that is, from the period 1279-1213 BCE. Thus they also fall within the nineteenth and twentieth dynasties. I personally don't consider this reading entirely implausible, especially the lines "Thou causest me to see darkness by day" (Stela BM 3274 and TT 218); "he caused me to behold darkness by day" (Stela BM 589 and Turin 50058); or "thou causest me to see a darkness of thy making" (Stela Turin 50046). On the contrary, the acknowledged expert on such phraseology, Jan Assmann, considers this reading questionable. He argues that many convincing examples support the view that "to see darkness by day" can only refer to blindness or to the experience of having lost touch with divine favor.[29]Be this as it may. None of these passages include an iconic illustration of a solar eclipse like the one I am proposing from tomb KV9. [30]

\section{SOlar ECLIPSES AS OMENS}

We know that solar eclipses were regarded as particularly unfavorable omens from one event that occurred on 30 September 610 BCE, just at the start of the Amun-Ra festival.[31] A material scientist 
from Cambridge and a freelance astrophysicist jointly reinterpreted a passage from the Book of Joshua (10: 12-14) in the Old Testament as indicating a solar eclipse in the year 1207 BCE. It describes the sun and the moon coming to a halt at Joshua's command. But this reinterpretation is controversial.[32]Espenak (2009) lists four other candidates for records of a solar eclipse prior to 1000 BCE, but they all relate to Ancient Chinese or Babylonian sources. Solar eclipses have inspired doubt in the power and probity of the governing ruler in many other cultures the world over - the Babylonians, Mayan and Aztek cultures and medieval Christians, to name just a few.[33]

According to Fritz Abitz's analyses (1989), the inscriptions in the front section of tomb KV9, originally conceived for Ramesses $\mathrm{V}$, were overwritten and redesigned by his successor apart from a few relics.[34] Nevertheless, they strongly resembled each other. Both were titled King of Upper and Lower Egypt, ruler of both lands, Lord of Rituals and Son of Ra,[35] sharing the same religious and cultic beliefs as great worshippers of the sun deity Amun-Ra. In the eighteenth-twentieth dynasties there was a crisis regarding the accepted polytheistic imagery. In the mid-fourteenth century BCE, Amenophis IV (Echnaton) had tried to impose the monotheistic belief, but his successors had backtracked and attempted to "convey faith in a transcendental supreme [sun] god Ra in a world of polytheism," in whose variegated image his - intrinsically hidden - unity becomes apparent."[36] Thebes, in particular, whose patron god was Amun-Ra, the state divinity, practised a "hypercosmic" understanding of the sun god manifested "encosmically" as the sun but reaching far beyond the cosmic into "supernatural occultation" ("überweltlich Verborgene"). Precisely this ineffability is displayed in a solar eclipse.

An examination of the preserved mummy of Ramesses $\mathrm{V}$ found that he had died of chicken pox at a young age. The end of his reign in $1145 \mathrm{BCE}$ had thus evidently come unexpectedly. The severely mutilated remains of his uncle successor Ramesses VI (grave robbers had chopped off the mummy's hands and shattered the skull to get at the jewelry) showed that he had lived to middle age.[37] A CT scan of the mummy of his father Ramesses III (the grandfather of his nephew predecessor Ramesses V) found that he had been a victim of murder. This assassination was surely related to the political unrest that broke out in the twentieth dynasty, after the 'seafaring nation from the eastern Mediterranean,' the Nubians, Syrians and Libyans had led a number of partly successful assaults on Egyptian territory that could only be staved off at great cost. This was followed by some years of drought. The low flood levels of the Nile resulted in famine and civil disobedience - the first historically documentable labor strike - and corruption. All of these problems still existed during the reigns of Ramesses V and VI.[38] That probably also explains why Ramesses V was laid to rest so late in a provisional tomb, two years after his death and well into the reign of Ramesses VI, against ritual rules. The fact that upon ascending the throne in 1145 Ramesses VI first had to defeat the Libyan invaders and drive them out of Thebes also explains why KV9 became the shared tomb of Ramesses V and VI.[39] Ramesses VI died in 1137 BCE.

The decorations at the front end of this 117-meter-long tomb were prepared rather hastily, perhaps shortly after the sudden death of Ramesses V. The style of the reliefs and murals that had been "tacked on" in the rear section of the tomb for Ramesses VI is different and partly more elaborately designed.[40]

\section{DATING THE SOlar ECLIPSE}

The placement of the image under discussion behind the end of the part of the tomb intended for Ramesses V suggests that an event which occurred during the early regency of Ramesses VI is what is being depicted. If this should indeed be the first preserved iconographic representation of a solar eclipse, it is an easy matter to suggest a likely date. Solar eclipses are relatively rare and can be calculated retrospectively for many centuries back using modern methods of astrometry. The canon of solar eclipses from 2501 BCE to 1000 A.D. which Rita Gautschy in Basel has made generally available on the Internet is useful for our case. [41]

As the reign of Ramesses V began in 1150 BCE and the one of Ramesses VI ended in 1133 BCE, we only need to comb through the chart entries of this solar eclipse canon for a period of eighteen years, working on the assumption that our depiction is of a solar eclipse that occurred during their reigns. The chart lists absolutely no total solar eclipses visible from Thebes during this period. The last one prior to that occurred in $1257 \mathrm{BCE}$, and the first one afterwards was in $1062 \mathrm{BCE}$. However, on 11 November 1143 BCE, we do hit upon a partial solar eclipse that, seen from Thebes, obscured about 
$80 \%$ of the sun's disk and even more so further South, thus only leaving a narrow sicle-shaped area visible just like the one in our image. This solar eclipse occurred in Thebes around 15:38 and lasted for 9 minutes and 43 seconds (according to https://eclipse.gsfc.nasa.gov/SEcat5/SE-1199--1100.html) with a maximum occultation of the sun's disk of $80.8 \%$. As a map of this solar eclipse in 1143 BCE, likewise accessible in this canon, shows (Fig. 8), its full totality zone lay south of Thebes near Swenet or Syene in the modern-day region of the Assuan dam, in the area still under pharaonic control.

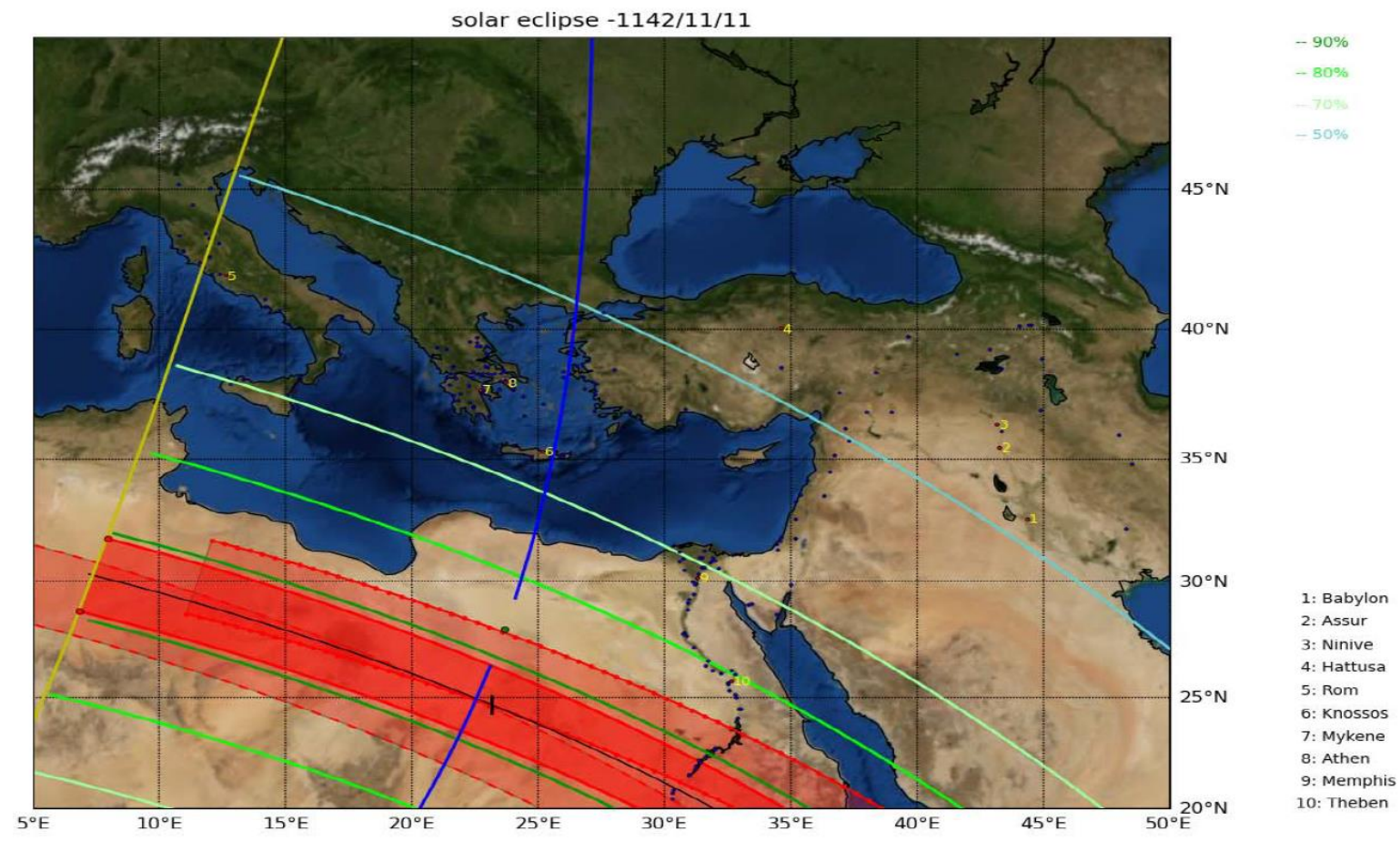

Fig. 8 Map of the full totality zone (red) in Southern Egypt, and of the occultation zones at 90, 80 [running through Theben, marked as yellow 10], 70 and 50 percent (green) in Egypt and Mesopotamia on 11 Nov. 1143 BCE (= -1142 in astronomical year-count). (From http://www.gautschy.ch/ rita/archast/solec/PLOTS/1200v/ solec-11421111.png with kind permission of Dr. Rita Gautschy)

It is thus certain that this relatively significant partial eclipse of the sun (of $>80 \%$ ) was noticed South of Theben and even more so further South in Egypt where it was a total eclipse which must surely have caused a sensation. We have numerous testimonies from other ancient cultures about the agitation such events caused. Whoever has experienced one knows how overwhelming this natural spectacle is: The quite surprising chilling dimming that persists for a few unnerving minutes, followed by a gradual return of the brightness of day. It was self-evident that this was an omen, a sign from the gods, especially at a time when Ramesses V and VI were attaching supreme importance to the sun or the sun deity Ra and lauding themselves as "sun of the kings" and as the "sun of mankind, dispelling darkness from Egypt".[42] A sudden unannounced and then totally incomprehensible occultation of the sun must have caused great confusion and doubt concerning the almightiness of the pharaoh - the reappearance of the sun after nearly 10 minutes would have been interpreted as a successful battle of $\mathrm{Ra}$ against the evil gods of darkness. Comparatively speaking: The Greek historian Herodotus reported about the momentous effect that the solar eclipse on 28 May 585 BCE had in the sixth century BCE. The Lydians and the Medians who were supposedly fighting a battle on that very day "not only ceased to fight, but both worked that much harder to conclude peace."[43]

Ramesses VI, who had been ruling since 1145 BCE., must have considered this solar eclipse on 11 November 1143 BCE important enough to have it depicted soon afterwards in a prominent spot in tomb KV9 originally cut for his predecessor, where at this time extension work from corridor D onwards was already underway. The place chosen was a singular, irregular part of the ceiling, located at the end of the excerpts from the first to the eleventh hours of Amduat on the walls of corridor $\mathrm{F}$ and G (see Figs. 1-2). Now, instead of the description of the rebirth of the sun in the twelfth hour, we have an image of a solar eclipse (Fig. 2) with the reaction of its observers; an image which so far has not found a satisfactory interpretation since it is not part of the Amduat sequence on all walls and ceilings before this spot and has not been plausibly interpreted otherwise. No similar scene of two nearly 
completely overlapping full circles (without any carrier), accompanied by two pairs of by-standing figures with instruments at their feet and looking at this central circle has been found in any other grave. If my interpretation of this very unusual ceiling mural at the end of corridor $\mathrm{G}$ is correct, we have one of the first-if not the very first-preserved visual representation of a solar eclipse, depicting the observers holding their music instruments in stunned awe at this divine spectacle of nature. Of course, I do not claim this new interpretation to be the only permissible one, but I would be grateful if the mere possibility that this image is representing a specific event, not a merely symbolic depiction of the moon, were discussed among Egyptologists, cultural historians and historians of astronomy.

\section{ACKNOWLEDGMENTS}

Many thanks to my wife Ann for translating this article. Unless otherwise indicated, all translations of foreign secondary sources are hers. I also thank for permissions to reproduce the figures. I am grateful to Professors emeritus Jan Assmann (Constance) and Andreas Kleinert (Halle) for comments to an earlier version of this paper. Furthermore I thank Dr. Rita Gautschy for the permissions to reproduce a figure.

\section{REFERENCES}

[1] For descriptions of KV9 see, i.a., Piankoff 1953, Piankoff and Rambova 1954, Hornung 1982, pp. 19, 40f., 126ff., 154ff. passim, 1988, Abitz 1989, Dodson and Ikram 2008, pp. 227-229, Reeves and Wilkinson 1996, pp. 117-119 besides other Internet pages listed at the end of this paper.

[2] See Hornung 1982, 1997.

[3] See"Pharaoh Ramses VI Tomb". Egyptian Tourism Authority. 2020-04-15. Accessed 30 July 2020.

[4] Piankoff and Rambova 1954, p. 435 interpret these instruments as "a composite sign of a heart surmounted by the sign for stability." In an email from 20 Sep. 2020 Jan Assmann said that he admits the strong similarity to a sistrum but still prefers the cryptographic interpretation as a combination of the hieroglyph nefer (beautiful), previously interpreted as a lute but later regarded anatomically as "heart plus windpipe," where the symbol for jeb(heart) appears to inscribe the hieroglyph weba (to open). Likewise for the sistrum above it: Assmann interprets it as the symbol for "powerful".

[5] On hymns of the sun cult and the adulatory divine world, of which the pharaoh as high priest was a part, see Assmann 1970, 1983, pp. 29, 39, 50f., 68f. passim.

[6] Darnell 2004, pp. 224ff., see below.

[7] See Piankoff and Rambova 1954, pp. 435-437 and plate 181, Darnell 2004, p. 224. On this birthing scene for the rising sun, cf. Assmann 1983, p. 65.

[8] Another parallel of this exchange is presented on the right-hand side of the main section in corridor G. See Darnell 2004, plate 16. On the opposition between time everlasting and unchangeable permanence (djet), which is personified by the sun deity Ra and mutable time of becoming and elapsing (neheh), comp. Hornung 1982, pp. 107ff., 114ff., 198 and Hornung 1997, pp. 48, 162-4, 185-190 as well as Assmann 2012.

[9] „eine große Sonnenscheibe mit der Mondsichel“ darunter, „sicher hier diese Vereinigung von Tag und Nacht oder der Dat mit dem Himmel.“ Abitz 1989, p. 154. Darnell 2004, p. 224 also espouses this interpretation.

[10] Piankoff and Rambova 1954, p. 435 merely say: "In the upper register there is a great disk placed in a crescent, with two male figures right and left."

[11] Abitz 1989, p. 154 (there referred to as the 5th corridor). This nightly union between Re and Osiris, day and night, in the 12th hour of Amduat,see Assmann 1994, pp. 118, 2012, 77f.

[12] Cf., e.g., de Beler 2001, pp. 54, 119, Altmann-Wendling 2019 vol.2, or https://www.selket.de/aegyptischegoetter/chons/ for examples; Christian Leitz (Tübingen) also interprets our image in this iconographic tradition (email to KH, 27.9.20).

[13] For examples see the color plates in Hornung 1982, Reeves and Wilkinson 1996, etc.

[14] Hornung 1997, Robertson 2012.

[15] Abitz 1989, pp. 99ff., Darnell 2004, chap. 4.

[16] Abitz 1989, 154 and Darnell 2004, p. 224; Quack 2005: 31 has raised doubts about this interpretation.

[17] On this papyrus cf., inter alia, Pleyte and Rossi 1869-76, Tf. 133, Assmann 2005: 231f., Roccati 2011.

[18] On this pharaonic role as high priest of the sun and guarantor of regularity, see: Assmann 1983, pp. 19, $25 \mathrm{ff}$. 
[19] See Assmann 1983, p.79, Sellers 1992 and Müller 1999 on the invocation "so that the Sun does not darken itself."

[20] Schutzbild, as it is called by Abitz 1989.

[21] Hornung 1988, p. 46, Darnell 2004, p. 231.

[22] About this Livre de la Création du Disque Solaire, see Piankoff 1953, Hornung 1997 and Roberson 2012.

[23] Assmann in Bärnreuter (ed.) 2009, pp. 18ff.

[24] See e.g., Assmann 1994, pp. 111f., 2012: p. 73 on the focus of ancient Egyptian astronomical observations on regular, cyclical events; exceptions and irregularities were left aside.

[25] Hornung 1982, Romano 1997, Assmann 2005, p. 220. Parallels with the Christian worldview suggest themselves, with Jesus as the son of God on Earth enveloped in awe-inspiring brilliance.

[26] "am ta pet pa iten" from the Chronical of Prince Osorkon in the late ninth century (c. 830) BCE, parts of which have been translated into German by Krauss 1985 and Peust 2005.

[27] According to the Lexikon der Ägyptologie, vol. I, col. 513 and vol. V, col. 1087, the first textual traces about a solar eclipse are found in a Demotian papyrus (Berlin papyrus 13588) written in the $1^{\text {st }} \mathrm{c}$. BCE, but describing a solar eclipse in the 26th dynasty (on 30. Sept. 610 BCE) - cf. Erichsen 1956, Hornung 1966, Mark Smith 1991, Müller 1999.

[28] Smith 2017: p. 5.

[29] Assmann 1970, 1983 as well has his email with the author from 20 Sep. 2020.

[30] Cf. the recent plea for a stronger integration of textual and visual sources in the reconstruction of ancient knowledge and practices by the assyrologist John Steele 2020.

[31] See Krauss 1985, pp. 174f. and Smith 1991, as well as further references provided in footnote 27.

[32] See Humphreys and Waddington 2017 and some commentary on the paper in the Internet, e.g. http://scienceandsf.com/index.php/2017/11/01/solar-eclipse-of-1207bc-helps-to-date-pharaohs-interestingbut-im-not-so-sure-about-the-connection/

[33] See, e.g., Ossendrijver in Bärnreuther (ed.) 2009, p.59 on the strategies that the Babylonians employed to defuse such a "cosmic drama" as was a solar eclipse, which they interpreted as "the sun god weeping." For cultural comparisons of solar images see Bärenreuter, ed. 2009 and Singh, ed., 1997.

[34] Abitz 1989 and https://nefershapiland.de/KV\%209\%20Ramses\%20VI.HTM

[35] Piankoff and Rambova 1954, 4, Abitz 1989, p. 147, passim.

[36] On this see Assmann 1983, pp. 3, 73, 98ff., passim, and Assmann in Bärnreuther (ed.) 2009, pp. 17f., 30ff.

[37] On the mummies found by V. Loret in 1898 in the tomb of Amenophis II (KV 35), see Abitz 1989, pp. 9ff., as well as http://www.crystallinks.com/dynasty-20.html and https://www.smithsonianmag.com/smartnews/ct-scan-shows-pharoah-Ramesses-iii-was-murdered-multiple-assassins-180958559/

[38] See von Beckerath 1997 and http://www.crystallinks.com/dynasty-20.html

[39] An ostracon (1.II.AHt) records the delayed burial of Ramesses V. See https://nefershapiland.de/KV\% 209\%20Ramses\%20VI.HTM

[40] On Ramessidian tomb architecture generally, see Assmann 2003 and Roberson 2008.

[41] See Fig. 8. For more about the computation methods and the residual uncertainty $\Delta \mathrm{T}$ of $27915 \mathrm{~s}=465$ min, see Gautschy 2012 and Stephenson (2008) who also discusses interesting examples from Chinese records. However, the exact time of the day on which the eclipse occurred is unimportant to me - if it were later in the day or earlier in the morning, the eclipse, then closer to the horizon, would rather have been more visible.

[42] Hornung 1965: p. 76; cf. also Müller 1999

[43] Herodotus: Historien 1,74,2; cf. Lorenzen 2016. It is surely a myth, though, that Thales of Miletus was the first to successfully predict a solar eclipse: see Neugebauer 1969, pp. 142f., 1975, 604f., Demandt 1970, pp. 25-29, Krauss 1985 and Wenskus 2016, pp. 3 ff. 
Web pages (all last accessed on 29 April 2021):

Interactive 3D-Scan of "Pharaoh Ramses VI Tomb": https://my.matterport.com/show/?m=NeiMEZa9d93\&mls $=1$

Descriptions of tomb KV9 with further links: https://en.wikipedia.org/wiki/KV9 and https://www.tagip edia.com/tdata/content_services/22/topics/adgjxx/descriptionandhttps://nefershapiland.de/KV\%209\%20Ramses \%20VI.HTM and https://egyptopia.com/en/articles/Egypt/Tomb-of-Ramses-VI-\%28KV-9\%29.s.29.13794/ and http://www.kv5.de/html_german/data_kv9_german.html

Maps of the solar eclipse of 1143 BCE (= -1142 astronomical year-count): http://www.gautschy.ch/ $\sim$ rita/archast/solec/PLOTS/1200v/solec11421111.png https://eclipse.gsfc.nasa.gov/SEsearch/SEsearchmap. php?Ecl=-11421111

Dirk Lorenzen: Vor 2600 Jahren. Erste vorausgesagte Sonnenfinsternis tritt ein, https://www.deutschlandfunk .de/vor-2-600-jahren-erste-vorausgesagte-sonnenfinsternis-tritt.871.de.html?dram:article_id=355360

https://de.wikipedia.org/wiki/Sonnenfinsternis_vom_28._Mai_585_v._Chr.

David G. Smith: Total solar eclipses in Ancient Egypt - a new interpretation of some New Kingdom texts, http://www.egiptomania.com/EEF/Blindness.pdf republished in modified form in Egypt logical (Aug. and Oct. 2012).

Forum discussions about Egyptian solar eclipses in the Egyptologist's Electronic Forum (EEF) archives, Thread "Eclipses and New Moons", September 1998: http://egyptologyforum.org/archeef/Sept98.ZIP and in http://www.aegyptologie.com/forum/cgi-bin/YaBB/YaBB.pl?board=jut\&action=display\&num=1075380946

http://scienceandsf.com/index.php/2017/11/01/solar-eclipse-of-1207bc-helps-to-date-pharaohs-interesting-butim-not-so-sure-about-the-connection/

Espenak, Fred: Solar eclipses of historical interest NASA Eclipse Web Site (2009) http://eclipse.gsfc.nasa.gov/ SEhistory/SEhistory.html

https://archiv.ub.uni-heidelberg.de/propylaeumdok/2306/on the chronicle of Prince Osorkon

https://www.selket.de/aegyptische-goetter/chons/andhttps://en.wikipedia.org/wiki/Khonsuon representations of the moon god Chons / Khonsu

https://en.wikipedia.org/wiki/Sistrum for various depictions of old sistrums from Ancient Egypt.

\section{Literature Cited:}

Abitz, Friedrich, Baugeschichte und Dekoration des Grabes Ramses VI (Fribourg: Universitätsverlag and Göttingen: Vandenhoeck and Ruprecht (= Orbis Biblicus et Orientalis [OBO] 89) (1989).

Altmann-Wendling, Victoria, MondSymbolik, MondWissen - Lunare Konzepte in den ägyptischen Tempeln griechisch-römischer Zeit, Wiesbaden: Harrassowitz, (2019).

Assmann, Jan, Der König als Sonnenpriester. Ein kosmographischer Begleittext zur kultischen Sonnenhymnik in thebanischen Tempeln und Gräbern, Glückstadt (= Abhandlungen des Deutschen Archäologischen Instituts, Abt. Kairo,no. 7)(1970).

Assmann, Jan, Re und Amun. Die Krise des polytheistischen Weltbilds im Ägypten der 18.-20. Dynastie, Fribourg: Universitätsverlag / Göttingen: Vandenhoeck \&Ruprecht (= Orbis Biblicus et Orientalis, 51)(1983).

Assmann, Jan, Solar Discourse. AncientEgyptianWaysofWorldreading, Deutsche Vierteljahresschrift für Literaturwissenschaft und Geistesgeschichte. 68, pp. 107-123 (1994).

Assmann, Jan, 'The Ramesside tomb and the construction of sacred space', in Niger Strudwick and John H. Taylor, (eds.),The Theban Necropolis. Past, Present and Future,London, pp. $46-52$ (2003).

Assmann, Jan, Lux divina - Zur Theologie des Lichts im Alten Ägypten, in Erik Hornung and Andrea Schweizer (eds.),Die Weisheit der Schlange, Basel, pp. 201-238 (2005).

Assmann, Jan, Sternzeit und Steinzeit: Altägyptische Zeitvorstellungen, in Peter Gandolla and Dietmar Schulte (eds.) Was ist die Zeit?,Munich,pp. 69-78,(2012).

Bärnreuter, Andrea, (ed.), Sonne. Brennpunkt der Kulturen der Welt, Berlin: Staatliche Museen zu Berlin, Deutsche Bank Stiftung und Edition Minerva(2009).

Beckerath, Jürgen von, Chronologie des pharaonis chen Ägypten, Mainz: Zabern (1997).

de Beler, Aude Gros, Die Götter und Göttinnen Ägyptens, Frechen: Komet (2001). 
Darnell, John Coleman, The Enigmatic Netherworld Books of the Solar-Osirian Unity: Cryptographic Compositions in the Tombs of Tutankhamun, Ramesses VI and Ramesses IX (Fribourg: Universitätsverlag / Göttingen: Vandenhoeck\&Ruprecht(= Orbis Biblicus et Orientalis198, 2004); cf. also Quack 2005.

Demandt, Alexander: Verformungstendenzen in der Überlieferung antiker Sonnen- und Mondfinsternisse, Akademie der Wissenschaften und Künste Mainz. Abhandlungen der geistes- and sozialwissenschaftlichen Klasse,No. 7 (1970).

Dodson, Aidan and Ikram, Salima, The Tomb in Ancient Egypt, London: Thames and Hudson (2008).

Erichsen, W., Eine neue demotische Erzählung, in: Akademie der Wissenschaften und der Literatur Mainz. Abhandlungen der geistes- and sozialwissenschaftlichen Klasse, issue no. 2: pp. 49-81 (1956).

Gautschy, Rita, Sonnenfinsternisse und ihre chronologische Bedeutung. Ein neuer Sonnenfinsterniskanon für Altertumswissenschaftler, Klio. 94,pp. 7-17, (2012).

Herodotus. Historien $1,74,2$.

Hornung, Erik, Licht und Finsternis in der Vorstellungswelt Ägyptens, Studium Generale. 18, pp. $73-83$ (1965).

Hornung, Erik, Die Sonnenfinsternis nach dem Tode Psammetichs I, Zeitschrift für Ägyptische Sprache und Altertumskunde. 92, pp. 38-39,(1966).

Hornung, Erik, Tal der Könige. Die Ruhestätte der Pharaonen, Zurich and Munich: Artemis (1982).

Hornung, Erik, Zum Schutzbild im Grabe RamsesVI, in: Funerary Symbols and Religion, Kampen, ed. byJ.H.Kok, H. Milde and Wagtendonk, pp. 45-51 (1988).

Hornung, Erik, Die Unterweltsbücher der Ägypter,Düsseldorf and Zurich: Artemis and Winkler(1997).

Humphreys, Colin and Graeme Waddington, Solar eclipse of 1207 B.C. helps to date pharaohs,Astronomy and Geophysics. 58,5, pp. 39-42,(2017).

Krauss, Rolf, Sothis- und Monddaten: Studien zur astronomischen und technischen Chronologie Altägyptens, Hildesheim: Gerstenberg(1985).

Lorenzen, Dirk: Vor 2600 Jahren. Erste vorausgesagte Sonnenfinsternis tritt ein: Deutschlandfunk,(28 May 2016).

Müller, Ingeborg, Der Himmel hat die Sonne verschlungen, aMun: Magazin für die Freunde ägyptischer Museen.Issue 3 (1999).

Neugebauer, Otto, The Exact Sciences in Antiquity, 2nd ed., New York: Dover Publ..(1969).

Neugebauer, Otto, A History of Ancient Mathematical Astronomy, Vol. 2, Berlin: Springer (1975).

Peust, Carsten, Aus der Chronik des Prinzen und Hohepriesters Osorkon (Jahr 11 Takeloths II.), in: Staatsverträge, Herrscherinschriften und andere Dokumente zur politischen Geschichte., Gütersloh, Texte aus der Umwelt des Alten Testaments, newser., 2, pp. 272-278 (2005).

Piankoff, Alexandre, La Création du Disque Solaire,Kairo:Institut Français d'Archéologie Orientale (1953).

Piankoff, Alexandre and Natasha Rambova, The Tomb of Ramesses VI, Vol. I: Texts. Vol. II: Plates, New York: Pantheon 1(954).

Pleyte, Willem and Rossi, Francesco, Papyrus de Turin, Leiden: Brill (1869-1876).

Quack, Joachim Friedrich, Ein Unterweltsbuch der solar-osirianischen Einheit?,Die Welt des Orients. 35, pp. 22-47 (2005) (= essay review of Darnell 2004).

Reeves, N. and Wilkinson, R.H., The Complete Valley of the Kings, London: Thames and Hudson (1996).

Roberson, Joshua Aaron, The Rebirth of the Sun: Mortuary Art and Architecture in the Royal Tombs of New Kingdom Egypt, Expedition, vol. 50, no. 2, pp. 14-25 (2008).

Roberson, Joshua Aaron, The Ancient Egyptian Books of the Earth, Atlanta: Lockwood Press (2012).

Roccati, Alessandro, Magica Taurinensia: II grande papiro magico di Torino e $i$ suoi duplicati (Rom. Gregorian and Biblical Press = Analecta Orientalia, 56, 2011)

Romano, James F., Die Sonnenkultur im alten Ägypten, in: Madanjeet Singh (ed.), Die Sonne. Das Gestirn in der Kulturgeschichte, pp. 321-333, Tübingen: Wasmuth (1997).

Sellers, Jane B., The Death of Gods in Ancient Egypt, Harmondsworth: Penguin Press (1992). 
Singh, Madanjeet ( ed.), Die Sonne. Das Gestirn in der Kulturgeschichte. Berlin: Wasmuth 1994.

Smith, David G., Total solar eclipse in Ancient Egypt - a new interpretation of some New Kingdom texts (2007), accessible online at http://www.egiptomania.com/EEF/Blindness.pdf

Smith, Mark, Did Psammetichus I die abroad?,Orientalia LovaniensiaPeriodica.22, pp. 101-109 (1991).

Smith, Mark, Following Osiris. Perspectives on the Osirian Afterlife from Four Millenia, Oxford: OUP (2017).

Steele, John, How can we incorporate visual evidence into the history of astral sciences in Mesopotamia?.NTM. 28, pp. 305-324 (2020).

Stephenson, F. Richard, How reliable are archaic records of large solar eclipses? Journal of the History of Astronomy. 39, pp. 229-250 (2008).

Wenskus, Otta, Die angebliche Vorhersage einer Sonnenfinsternis durch Thales von Milet: Warum sich diese Legende so hartnäckig hält und warum es wichtig ist, ihr nicht zu glauben, Hermes. 144, pp. 2-17 (2016).

\section{AUTHOR'S BIOGRAPHY}

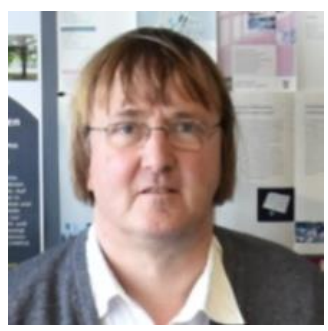

Klaus Hentschel (1961), has studied physics (with a diplome in high-energy physis), philosophy (with a master's thesis in philosophy of science) and history of science at the University of Hamburg. His dissertation on philosophical (mis)interpretations of Einstein's theories of relativity was published in 1990 and his habilitation on the interplay of scientific instrumentation, experimentation and theory formation in spectroscopy and astrophysics 1998. He lectured and researched at the universities of Berlin, Bern and at MIT in Cambridge, Mass. He also was Ernst Cassirer guest professor at the University of Hamburg. Since 2006, Klaus Hentschel is full professor for the history of science and technology at the University of Stuttgart. He published 10 books, edited more than 20 anthologies and editions and more than 150 papers. Especially pertinent to the topic of this article is his comparative history of Visual Cultures in Science and Technology (Oxford 2014) and his anthology of papers on The Role of Visual Representations in Astronomy (2000). For a full list of his publications see https://www.hi.uni-stuttgart.de/institut/team/Hentschel/; several of them are freely downloadable at https://www.researchgate.net/profile/Klaus-Hentschel

Citation: Klaus Hentschel. "Depiction of A Solar Eclipse from 1143 BCE in the Pharaonic Tomb KV9 near Thebes" International Journal of History and Cultural Studies (IJHCS). vol 7, no. 2, 2021, pp. 11-23. doi: DOI: https://doi.org/ 10.20431/2454-7654.0702002.

Copyright: (C) 2021 Authors. This is an open-access article distributed under the terms of the Creative Commons Attribution License, which permits unrestricted use, distribution, and reproduction in any medium, provided the original author and source are credited. 